\title{
Regrowth of Napier Grass (Pennisetum purpureum Schumach) with the Bio- pore Infiltration Hole in the Tropical Riparian Moonson Region
}

\author{
Gusti Rusmayadi *, Rahmi Zulhidiani, Bahrani \\ Agronomy Study Program, Department of Agriculture Cultivation, Agriculture Faculty, \\ Lambung Mangkurat University (ULM), South Borneo, Indonesia
}

\section{Article history:}

Submission January 2020

Revised June 2020

Accepted June 2020

${ }^{*}$ Corresponding author:

E-mail: gustirusmayadi@ulm.ac.id

\begin{abstract}
Technology water and rainfall in doing to reduce soil water deficit in the soil. The technology is bio-pore that formed living things, such as soil fauna and crop roots. This study uses a single factor randomized block design environment (RBD). The factor studied was the Bio-pore Infiltration Hole $(\mathrm{BIH})$, which is filled with organic matter. The treatment was repeated 4 times, so that 20 experimental units were obtained. The treatments consisted of A (without BIH) as a control, B (BIH + Dry leaves), C (BIH + cow dung), D (BIH + chicken manure), and E (LR B + cow manure). Napier grass cropped with a spacing of $50 \times 50 \mathrm{~cm}^{2}$ that wasobserved for variables of crop height, wet weight and dry weight of crops per bundle. The ground water content is measured with soil boring, and rainfall is measured with an ombro-meter. The study was conducted in the Experimental Garden of the Faculty of Agriculture, Sei Riam Village, Pelaihari Subdistrict, Tanah Laut Regency, with a time of 2 months from November to December 2019. Rainfall in November and December was $127.85 \mathrm{~mm}$ and $637.8 \mathrm{~mm}$ with uneven distribution. The ground water content in treatments $\mathrm{BIH}+$ cow dung, $\mathrm{BIH}+$ cow dung, $\mathrm{BIH}+$ chicken manure, and $\mathrm{BIH}+$ cow manure is different from without BIH because it is without organic matter so that its ability to retain water is small and its content is also less. Growth of crop height variable between 187.16 to $191.85 \mathrm{~cm}$, wet weight in the range of $12.1 \mathrm{~kg} / \mathrm{m}^{2}$ - a $14.9 \mathrm{~kg} / \mathrm{m}^{2}$, and the dry weight in the range of $3.9 \mathrm{~kg} / \mathrm{m}^{2}-4.6 \mathrm{~kg} / \mathrm{m}^{2}$, so treatments $\mathrm{B}, \mathrm{C}, \mathrm{D}$, and E gave the best response compared to A which generates crop height about $172.78 \mathrm{~cm}, 7.3$ $\mathrm{kg} / \mathrm{m}^{2}$ wet weight and $2.4 \mathrm{~kg} / \mathrm{m}^{2}$ dry weight.
\end{abstract}

Keywords: Bio-pore, napier grass, organic materials, soil water content

\section{Introduction}

Crop growth on dry land is directly influenced by climate elements, especially rainfall, whose distribution is uneven throughout the year. The limitation of water in dry land has an impact on forage crops which cannot produce optimally throughout the year.

Water and climate management technology innovations are needed to reduce the ground water deficit on land which includes rain harvesting techniques, rain prediction, determination of cropping time, and cropping patterns. Harvesting water can be done by collecting rainwater or surface runoff in temporary shelters or harvesting is used to irrigate crops (Subagyo et al., 2000). One form of rainwater storage is bio-pore which according to (Brata\&Nelistya) is a pore in the soil formed by living things, such as soil fauna and crop roots. This form of bio-pore infiltrates small tunnels or burrows and branches which are very effective for delivering water to and in the ground. Hole on bio-pore formed by the growth and development of crop roots in the soil as well as increasing activity of soil fauna, such as earthworms, termites, and ants that dig hole in the ground. The number and size of bio-pore will continue to increase following the growth of crop roots and increasing population and activity of soil organisms.

\section{How to cite:}

Rusmayadi G, Zulhidiani R, Bahrani (2020) Regrowth of Napier Grass (Pennisetum purpureum Schumach) with the Biopore Infiltration Hole in the Tropical Riparian Moonson Region. Journal of Agriculture and Applied Biology 1 (1): 18 - 24. doi: 10.11594/jaab.01.01.03 
Bio-pore infiltration holes (BIH) made se vertically shaped cylindrical drill with diameter $10 \mathrm{~cm}$ and deep is not over the ground water level, which is $80-100 \mathrm{~cm}$ of the soil surface. The distance between the holes are $100 \mathrm{~cm}$. The hole can be reformed by cement width of $2-3 \mathrm{~cm}$ with a thickness of $2 \mathrm{~cm}$ around drill. The hole is filled with organic waste (kitchen waste, crop residues, leaves or grass trimming). The waste will become compost which can then be used for crop fertility.

The BIH technique is developed based on the eco-hydrological principle, which is to improve the condition of soil ecosystems to improve the hydrological function of the ecosystem. Utilization of organic waste into small and deep holes, apparently can create good habitats for a variety of soil organisms, especially earthworms. Existing studies indicate that earthworms effectively make holes only in the topsoil layer $(0-25 \mathrm{~cm})$ and the subs oil layer $(25-50 \mathrm{~cm})$, either under the layer or deeper, practically not affected by earthworm activity. The hole in the hole is assumed to be $30 \%$ to $40 \%$ of the volume of organic waste put in the hole.

The results of the analysis showed that when the intensity of the rain was low, almost all the water was absorbed, but when the rainfall intensity was greater the percentage of water that was abundant was greater. BIH can accelerate the absorption of rain and overcome organic waste to prevent waterlogging and flooding, and to avoid erosion and landslides. In addition, organic waste piled up in holes can also be used as compost, while increasing soil fertility and increasing water supply. South Kalimantan's land resources are quite extensive, which is around $37,377 \mathrm{~km}^{2}$ with agroecosystem conditions such as dry land, tidal land, rain-fed, back-swamp and others play an important role in its contribution to the potential forage availability of feed (Animal Husbandry Department of South Kalimantan Province, 2011). The constraints faced in this sub-sector are limited sources of forage. This is due to the use and selection of productive land is often used for food crops. Utilization of dry land is one alternative that can be done to overcome the provision of forage.
Tanah Laut Regency is a regency in South Kalimantan that has dry land. The dry land area in this region is 247,043 hectares, possible for development of forages. One of the areas of animal husbandry development is the Pelaihari sub-district which has an annual rainfall greater than $2,500 \mathrm{~mm}$ with a monthly average of $223 \mathrm{~mm}$ with a Monsoon pattern. According Oldeman climate classification this area has climate type $\mathrm{C} 2$ one year only one cropping of paddy and second crops are being careful not to fall in the dry. This area has five months wet since November to April and two month dry since August to September (Rusmayadi et al., 2017).

Sources of food in dry land are quite diverse and varied, apart from those sourced from grazing land and sourced from public land, so far it serves as a supplier of HMT (Forage for Animal Food). The ability of HMT's supply power will decrease without efforts to improve and preserve vegetation. Related to the increase in livestock population, if there is no exploration of feed sources, there will be a shortage of feed needs in the dry season which often occurs in dry land areas. Optimizing the use of water resources in dry land is the focus of attention in various studies and research this time. Generally, the goal of the research is gain availability of water, extending the growing season and reduce the risk of yield loss in order to create dry land farming system sustainable. Therefore, it is necessary to apply applied technology as an alternative to overcome the problem of developing green fodder (HMT) in riparian areas and dry land. Regrowth (grass regrowth) is the result of crop metabolism after experiencing defoliation that affects crop productivity. Factors that affect grass productivity are basically genetic and environmental factors which include soil fertility, climate influences and human or management treatment. Then, grass productivity depends on factors such as persistence, aggressiveness, ability to regrowth, dry and coldresistant properties, spread of seasonal production, soil fertility, and climate.

It is therefore possible that aim of this research a response to regrowth of Napier grass and the best response is regrowth of Napier 
grass crops in the bio-pore infiltration system in dry land.

\section{Material and Methods \\ Material and Apparatus}

Equipment used is metered, soil drill, corkdrill, camera digital, grass cutting, ombrometer, oven, weight balance. Materials used are Napier, which already defoliation at height $10 \mathrm{~cm}$, organic matter had dry leaves, cow dung, cow manure, and chicken manure as a treatment in the study.

\section{Material of Experiment}

This research is a field study using a single factor randomized block design environment (RBD). The factor studied was the bio-pore infiltration holes (BIH) factor which was given organic material. Each treatment was repeated 4 times, so as many as 20 plot units were obtained.

The treatments in this study were A (without $\mathrm{BIH}$ ) as a control, B (BIH + Dry leaves), C (BIH + cow dung), D (BIH + chicken manure), and $\mathrm{E}$ (BIH + cow manure). The observed variables were number of tillers per clumps, leaf area, crop height, fresh and dry grass per bundle. Groundwater content measured by sensor type 303 Digital Multimeter (Rusmayadi\& Budianto, 2009) and rainfall measured by Ombrometer.

\section{Time and Site}

The study was conducted in the Experimental Garden of the Faculty of Agriculture, Sungai Riam Village, Pelaihari Sub-district, Tanah Laut Regency, South Kalimantan Province with the implementation time for 2 months from November to December 2019.

\section{Research Conducted}

The land has been cropped with Napier grass. Defoliation is done by cutting Napier grass as high as $10 \mathrm{~cm}$ from the ground surface. Manufacture bio-pore infiltration holes (BIH) starts with digging the ground using a boring ground as deep as $80 \mathrm{~cm}$, cylindrical, and the hole diameter of $10 \mathrm{~cm}$. Then, organic matter is put into the bio-pore hole with a dose, namely dry leaves $0.5 \mathrm{~kg}$, cow dung $2 \mathrm{~kg}$, chicken manure $2 \mathrm{~kg}$, and cow manure $1.5 \mathrm{~kg}$.

Observations were made on dry and wet weight per bundle about 3 times i.e after were 14 days, 28 had, and 42 days after defoliation (had). Observation wet and dry weight per bundle is done by observing the crop separation between the stems and leaves. The oven is dried in an oven at $70^{\circ} \mathrm{C}$ for $2 \times 24$ hours (constant weight) and weighing the wet and dry weight of the crop using analytical scales.

\section{Data Analysis}

Data on number of tillers per clumps, leaf area, crop height, leaf area, wet weight and dry weight per cluster were analysed by $\mathrm{F}$ test at $5 \%$ and $1 \%$ levels. Data is homogeneous with the Barlet-test. Then the Least Significant Difference (LSD) test was performed at the 5\% test level to determine the best response of each variable to the treatment. The additive linear model that postulated to the observed variables (Steel \& Torrie, 1980).

$$
\widehat{\boldsymbol{Y}}_{i j k}=\mu+\alpha_{i}+\beta_{j}+\varepsilon_{i j}
$$

Where, $\mathrm{i}$ is $1,2,3,4$, and 5 (BIH filled with organic material), $\mathrm{j}$ is $1,2,3$, and 4 (many groups) , $Y_{\mathrm{ijk}}$ is Response of regrowth of crops receiving $i$ treatment in group $j$, and $\mu$ ? is mean (average) general, $\alpha_{i}$ is effect of group $\mathrm{j}, \beta_{j}$ is effect of treatment $\mathrm{i}$, and $\varepsilon_{\mathrm{ijk}}$ effect of error randomized trial who received treatment to-i and $\mathrm{j}$.

\section{Results and Discussion \\ Rainfall and Soil Water Content}

Rainfall during the experiment was presented in Figure 1 below. Rain in November was $127.85 \mathrm{~mm}$ and December was $637.8 \mathrm{~mm}$ with uneven distribution. The average daily rainfall in December is higher than in November. The ground water content in the $\mathrm{BIH}$ treatment is different from the BIH (A) treatment because it is without organic material so that its ability to hold water is minimal. The field capacity (FC) of the study site was $42.3 \%$ and Permanent Wilting Points (PWP) was $13.9 \%$. 


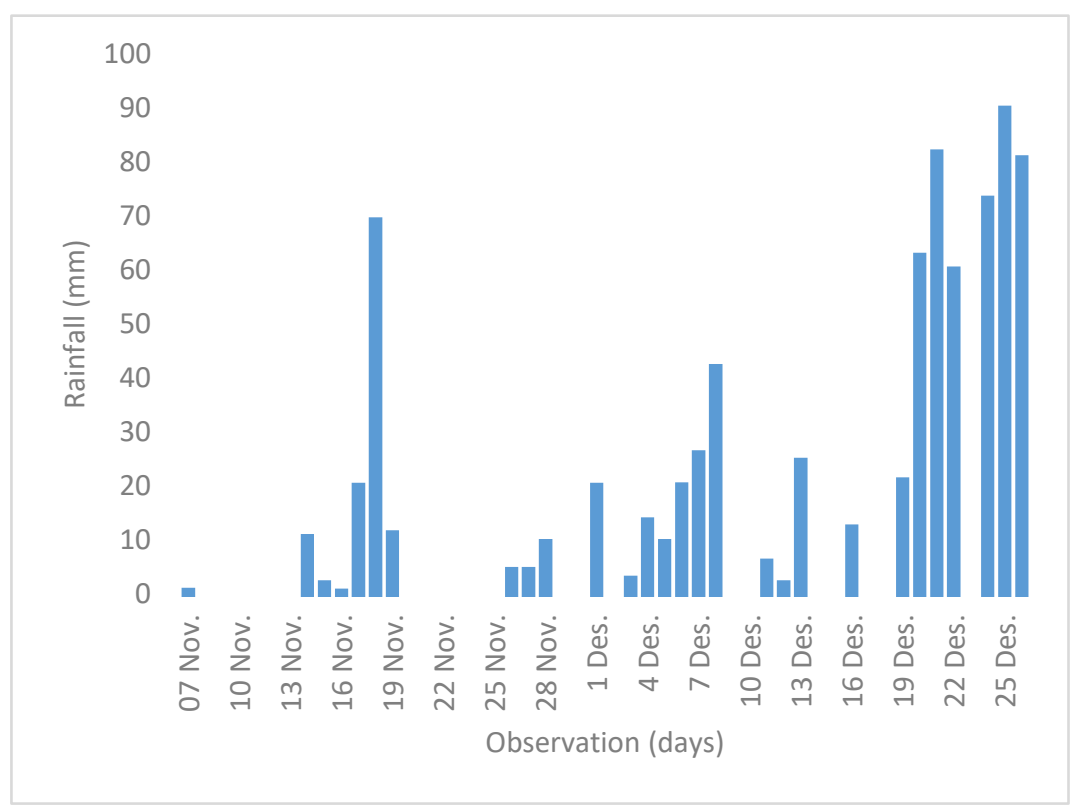

Figure 1. Rainfall during experiments

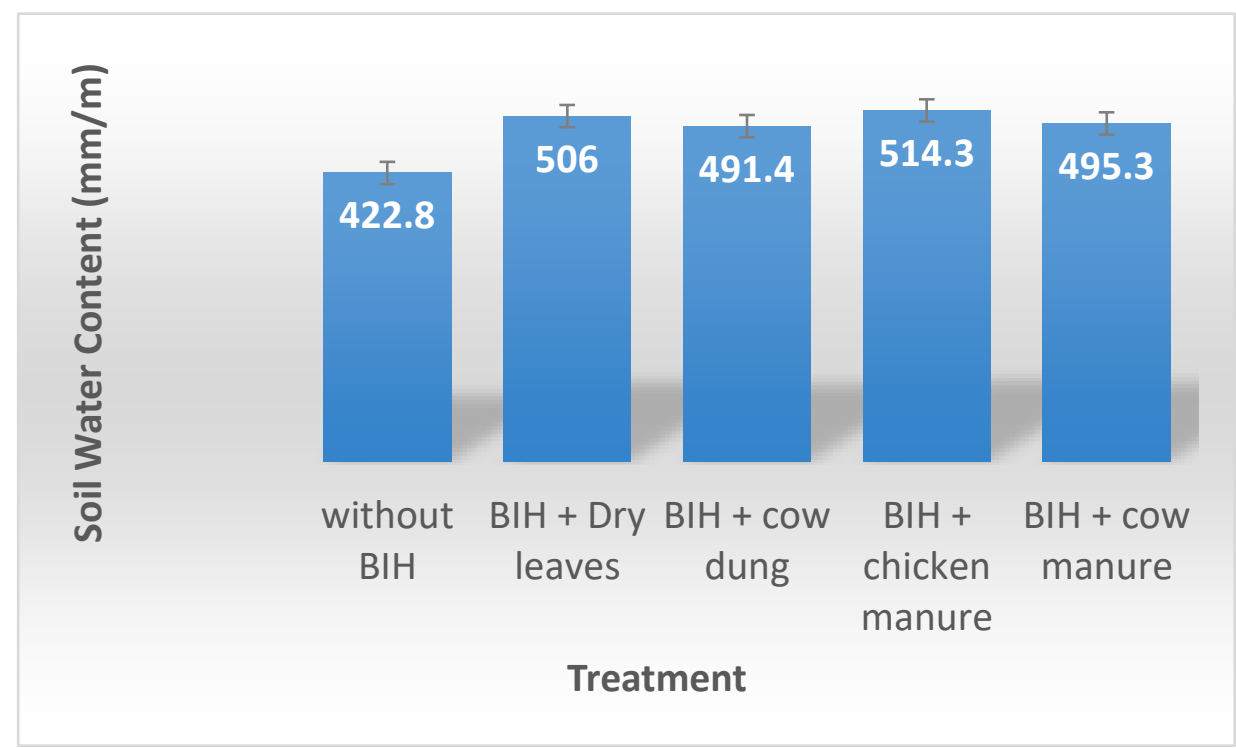

Figure 2. Groundwater content $(\mathrm{mm})$ of each treatment

\section{Agronomic Performance}

Some variables showed regrowth of the crop to the treatment BIH by organic materials provide the best response and significantly different treatment without $\mathrm{BIH}(\mathrm{A})(\mathrm{P}<0,05)$ at the variable crop height, fresh weight and the dry weight per hillside, but the response was not significantly different among treatment BIH by organic materials (Table 1). Number of tillers per clumps and leaf area was not significantly different $(\mathrm{P}>0.05)$ for all treatments (Table 1). 
$\underline{\text { Table 1. Effect of Treatment on Some Napier Grass Variables }}$

\begin{tabular}{lccccc}
\hline & \multicolumn{5}{c}{ Variables } \\
\cline { 2 - 7 } \multicolumn{1}{c}{ Treatment } & $\begin{array}{c}\text { number } \\
\text { of tillers } \\
\text { per } \\
\text { clumps } \\
\text { (ns) }\end{array}$ & $\begin{array}{c}\text { leaf area } \\
\left(\mathrm{cm}^{2}\right)(\mathrm{ns})\end{array}$ & $\begin{array}{c}\text { Crop } \\
\text { Height } \\
(\mathrm{cm})\end{array}$ & $\begin{array}{c}\text { Wet Weight } \\
\text { per bundles } \\
\text { of crops }(\mathrm{g})\end{array}$ & $\begin{array}{c}\text { Dry Weight } \\
\text { per bundles } \\
\text { of crops (g) }\end{array}$ \\
\hline A (without BIH) & 18.06 & 1952.76 & $172.78^{\mathrm{a}}$ & $1837.8^{\mathrm{a}}$ & $593.85^{\mathrm{a}}$ \\
\hline B (BIH + dry leaves) & 20.75 & 2000.00 & $191.85^{\mathrm{b}}$ & $3020.7^{\mathrm{b}}$ & $999.31^{\mathrm{b}}$ \\
\hline C (BIH + cow dung) & 17.56 & 2083.61 & $189.90^{\mathrm{b}}$ & $3129.2^{\mathrm{b}}$ & $1024.24^{\mathrm{b}}$ \\
\hline D (BIH + chicken manure) & 23.75 & 2034.40 & $187.16^{\mathrm{b}}$ & $3720.4^{\mathrm{b}}$ & $1149.35^{\mathrm{b}}$ \\
\hline E (BIH + cattle manure) & 21.38 & 2318.87 & $188.82^{\mathrm{b}}$ & $3429.4^{\mathrm{b}}$ & $1049.93^{\mathrm{b}}$ \\
\hline
\end{tabular}

Note: The average number followed by the same letter in the same column is not significantly different based on BNT at the $5 \%$ test level, ns = no real effect

Table 1 shows the treatment $\mathrm{A}, \mathrm{B}, \mathrm{C}, \mathrm{D}$, and $E$ on 42 days after defoliation are the same for the number of tillers per clumps with a range $17.56-21.38$ tillers per clumps, also the leaf area with a range $1952.76-2318.87 \mathrm{~cm}^{2}$. The height of crops with a range of 187.16 - 191.85 $\mathrm{cm}$, and together different from treatment $\mathrm{A}$ (without BIH) with a crop height of 172.78 $\mathrm{cm}$. Crop fresh weight per hill is also the same for the treatment of $\mathrm{B}, \mathrm{C}, \mathrm{D}$, and $\mathrm{E}$ with a range $3,020.4-3720.4 \mathrm{~g}$ per bundle or $12.1 \mathrm{~kg} / \mathrm{m}^{2}$ a $14.9 \mathrm{~kg} / \mathrm{m}^{2}$ which is different from the control treatment A with the weight $1837.8 \mathrm{~g}$ or $7.3 \mathrm{~kg} / \mathrm{m}^{2}$. The same pattern of the dry weight of crops, treatment B, C, D, and E with a range of $999,31 \mathrm{~g}-1149.35 \mathrm{~g}$ per bundle or $3.9 \mathrm{~kg} / \mathrm{m}^{2}-4.6 \mathrm{~kg} / \mathrm{m}^{2}$, which is different real with treatment A treatment with a weight of $593.85 \mathrm{~g}$ or $2.4 \mathrm{~kg} / \mathrm{m}^{2}$. C, D, and E treatments that containing manure fertilizer were also relatively higher compared to treatment $B$ (green fertilizer) for wet weight per bundles of crops and dry weight per bundles of crops.

The highest leaf area in the treatment although it did not differ due to the highest number of tillers compared to control A (without $\mathrm{BIH}$ ). The increase in leaf and plant area which is increased in height is followed by an increase in total dry weight of forage. These results indicate that an increase in the process of photosynthesis with a wider leaf width, resulting in a higher dry weight. Gardner et al.
(1991) states that the rate of photosynthesis will increase with increasing leaf area so that plant growth can be better. Number of tillers per clumps is not different because of the treatment to give on regrowth grass. This is because during the research the groundwater content in each media was in the field capacity (Figure 2) so that it was able to provide water for plants in optimal conditions. Elephant grass grows in areas with high rainfall up to 2,500 mm / year, or not less than $1000 \mathrm{~mm}$ / year, except on river sides. During the experiment, the field capacity of the study site was $42.3 \%$, higher than $31 \%$, which was classified as very high so there was sufficient water. This situation is in line with Haryadi states that water in optimal conditions allows certain hormones to work actively in the cell wall to stretch. This condition also stimulates the formation of sugars that can enlarge cells so that large vacuoles are formed. Crop height increase is the process of cell division and enlargement which is influenced by cell turgor. Number of tillers also affects the leaf area, so all treatment is the same effect. In the crop height is higher than the results of with an average crop height only between $60,13-72,50$ $\mathrm{cm}$. The wet weight of the crop is heavier than the results of the study (Sugandi et al., 1992) with an average production of fresh green $\mathrm{Na}-$ pier grass with recommended chemistry and cage fertilizer is $0.27 \mathrm{~kg} / \mathrm{m}^{2}$ and the other re- 
search (Seseray et al., 2013) with only chemistry fertilizer produce of $2.87 \mathrm{~kg} / \mathrm{m}^{2}$. Yet, these results are still lower than the study (Wayan, 1998) with high chemistry fertilizer doses, the average production of fresh Napier grass is $52.5 \mathrm{~kg} / \mathrm{m}^{2}$. Dry matter production was also higher than the results of (Seseray et al., 2013) research which has resulted in $0.68 \mathrm{~kg} / \mathrm{m}^{2}$. It is assumed that rainfall can increase ground water level (Figure 2) so that it is sufficient during the regrowth of crops in the BIH treatment which is given organic material. The response to regrowth of crops is shown in variables of crop height, wet weight per hill, and dry weight per hill. During experiment, the groundwater content was always at the field capacity so that these factors had a significant influence on crop regrowth in the treatment of $\mathrm{BIH}$ that were given organic material.

According to the results of the study (Kushartono, 2001) fresh forage production in the treatment of rainfall and fertilization can be obtained that the rainfall can support the production of Napier grass. Rainfall and the high production are very closely, especially on crops that need water quite a lot in the growth phase such as Napier grass. BIH also can improve the ability of the soil to absorb water. Water seeped through the wall surface BIH penetrates to the ground around the hole, so me add water reserves in the soil and prevent the flow of water in ground surface. Vegetation or crops on a land will be able to increase the water content of the field capacity and maximum water content. In figure 2 showed that all treatment, content water always at field capacity about $42.3 \%$ or 423 $\mathrm{mm} / \mathrm{m}$. This is caused by the provision of organic material, too. Organic matter can bind water up to six times its own weight, so that the ability of infiltration is high (Hakim et al., 1986)Cattle or green manure can maintain soil organic matter, increase biological activity, and increase groundwater availability. According to Ifradi, \& Elsifitriana (2003) the higher the ground water content, the better absorption and transportation of nutrients and water, so that the rate of photosynthesis to produce food reserves for plant growth is more secure and production will increase.
The availability of organic matter in the environment where crops grow can support the taking of nutrients by crops. Decomposition of organic matter will in turn provide the nutrients needed by crops, so organic matter is called a nutrient warehouse (Delgado \& Follet, 2002). It is strongly suspected that the macro and micronutrient content of organic matter has been decomposed well and the nutrients contained in organic matter have been released.

The treatments that containing manure from cattle and chicken were also relatively higher compared to treatment green manure for wet weight per bundles of crops and dry weight per bundles of crops. This is due to the nutrient content of manure cattle and chicken which is more complete than that of green manure.

\section{Conclusion}

Regrowth of crops on some variables on the treatment of BIH which were given organic material affected the variable height of cropping, wet weight per bundle, and dry weight per bundle crop.

Regrowth of crops on the variable like crop height, fresh weight per bundle, and dry weight per bundle provide the best response to the treatment of BIH given organic material compared to BIH without organic matter

\section{Acknowledgment}

Thank you to Sei Riam Park for facilities such as field experiments and other workers.

\section{References}

Delgado \& Follet. (2002). Carbon and Nutrient Cycles. Jurnal. Soail And Water Conserv, 57(6), 455-464.

Gardner, P. P., Pearce, R. B., \& Mitchell, R. L. (1991). Cultivation plant physiology (In Indonesia: fisiologi tanaman budidaya). Jakarta: Penerbit Universitas Indonesia (UI-Press).

Hakim, N., Nyakpa, Y., Lubis, A. M., Nugroho, S. G., Diha, M. A., Dihong, G. B., \& Bailey, H. H. (1986). Basics of soil science (In Indonesia: Dasar-dasar ilmu tanah). Lampung, Universitas Lampung.

Ifradi, M., \& Elsifitriana, P. (2003). Effect of manure and rice straw mulch on the production and nutritional value of king grass (Pennisetum purpuphoides) on Podzolik Merah Kuning soil (In Indonesia: Pengaruh pemberian pupuk kandang dan mulsa jerami padi terhadap produksi dan 
nilai gizi rumput raja (Pennisetum purpuphoides) pada tanah Podzolik Merah Kuning). Jurnal Peternakan dan Lingkungan, 10, 31-40.

Kushartono, B. (2001). Effect of Rainfall and Fertilization Patterns on King Grass Production (In Indonesia: Pengaruh Curah Hujan dan Pola Pemupukan Terhadap Produksi Rumput Raja). Temu Teknis Fungsional Non Peneliti, 42-49.

Rusmayadi, G., Arian, N. R., \& Ruslan, M. (2017). TRMM 3B43 rain data information in determining long wet and dry. RJOAS 11(71),

370-378. doi://doi.org/10.18551/rjoas.2017-11.48.

Rusmayadi, G., Budianto, B. (2009). Measurement of soil water content in jatropha planting pengukuran (In Indonesia: kandungan air tanah pada pertanaman jarak pagar (Jatropha Curcas L.) soil water. Jurnal Agromet Indonesia 23(1), 20-28.

Seseray, Y. D., Santoso, B., \& Lekitoo, M. N. (2013). Production of Elephant Grass (Pennisetum purpureum) which was given N, P, K Fertilizers at Doses of 0,50 and $100 \%$ on
Devoliation on the 45th day (In Indonesia: Produksi Rumput Gajah (Pennisetum purpureum) yang diberi Pupuk N, P, K dengan Dosis 0, 50 dan 100\% pada Devoliasi hari ke-45). Sains Peternakan 11(1), 49-55.

Steel, R. G., \& Torrie, J. H. (1980). Principles and Procesures of Statistics. New-York, McGrawa-Hill, Inc.

Subagyo, H., Suharta, N., \& Siswanto, A. B. (2000). Agricultural lands in Indonesia (In Indonesia: Tanah-Tanah Pertanian di Indonesia. Sumberdaya Lahan di Indonesia dan Pengelolaannya. Bogor, Pustlit Tanah dan Agroklimat.

Sugandi, D., Kusnadi, U., Sabrani, M., Sireger, M. E., \& Muslih, D. (1992). Cultivation of several types of feed plants in batumarta dry land (In Indonesia: Budidaya beberapa jenis tanaman pakan di lahan kering batumarta. Jurnal Ilmu dan Perternakan, 5(2), 87-91.

Wayan, I. (1998). Overview of Feed Material and Ration Formulation for Beef Cattle (In Indonesia Sekilas Bahan Pakan dan Formulasi Ransum untuk Sapi Potong), Balai Penelitian Ternak. 